\title{
Bioassay standardization issues in freshwater ecosystem assessment: test cultures and test conditions
}

\author{
Vera A. Terekhova ${ }^{1,4}$, Kirit Wadhia ${ }^{2}$, Elena V. Fedoseeva ${ }^{3,}{ }^{*}$ and Pavel V. Uchanov ${ }^{4}$ \\ ${ }^{1}$ Lomonosov Moscow State University, Moscow, Russia \\ ${ }^{2}$ National Oilwell Varco (NOV), Flotta, Stromness, Orkney, UK \\ ${ }^{3}$ Pirogov Russian National Research Medical University, Moscow, Russia \\ ${ }^{4}$ Severtsov Institute of Ecology and Evolution RAS, Moscow, Russia
}

\begin{abstract}
The use of bioassays for environment contamination assessment, in particular for aquatic ecosystems, has gained topicality and found extensive applications over the past decades. The methodologies are well established, but the standardization of bioassay conditions needs to be better defined in order to assure applicability as an efficient analytic tool and that results are ecologically relevant. This paper addresses the analysis of the current international situation and the specifics of Russian practice in culturing and use of test organisms for freshwater bioassays. Standardization of bioassays calls for the utilisation of pertinent sources of test cultures and the provision of appropriate cultivation conditions. The paper discusses and reviews recommendations for the selection of test species and their culturing in the context of established ecotoxicological targets and the assessment of sensitivity to various reference toxicants. The significance of the quality of water utilized for test cultures and sample dilution is highlighted. Strict water quality requirements and synthetic media options are analyzed and due consideration is given to temperature and illumination conditions. Toxkit microbiotests are discussed as an alternative to toxicity bioassays alleviating the need for continuous stock test culturing and maintenance.
\end{abstract}

Keywords: Toxicity tests / standardization / reference toxicants / culture and dilution water / test conditions / toxkit microbiotests

\begin{abstract}
Résumé - Questions de normalisation des essais biologiques dans l'évaluation des écosystèmes d'eau douce : cultures expérimentales et conditions des tests. L'utilisation des essais biologiques pour l'évaluation de la contamination de l'environnement, en particulier pour les écosystèmes aquatiques, est devenue d'actualité et a trouvé de nombreuses applications au cours des dernières décennies. Les méthodologies sont bien établies, mais la normalisation des conditions d'essais biologiques doit être mieux définie afin d'assurer, et l'applicabilité en tant qu'outil d'analyse efficace, et que les résultats sont écologiquement pertinents. Le présent document traite de l'analyse de la situation internationale actuelle et des particularités de la pratique russe en matière de culture et d'utilisation d'organismes de test pour les essais biologiques en eau douce. La normalisation des essais biologiques exige l'utilisation de sources pertinentes de cultures expérimentales et la mise à disposition de conditions de culture appropriées. Le document discute et examine les recommandations pour la sélection des espèces de test et leur culture dans le contexte des cibles écotoxicologiques traditionnelles et l'évaluation de la sensibilité à divers produits toxiques de référence. L'importance de la qualité de l'eau utilisée pour les cultures expérimentales et la dilution des échantillons est soulignée. Les exigences strictes en matière de qualité de l'eau et les options en matière de fluides synthétiques sont analysées et les conditions de température et d'éclairage sont dÛment prises en compte. Les tests microbiologiques Toxkit sont considérés comme une alternative aux essais biologiques de toxicité, ce qui réduit la nécessité de cultiver et d'entretenir les animaux en continu.
\end{abstract}

Mots-clés : Tests de toxicité / normalisation / substances toxiques de référence / eau de culture et de dilution / conditions d'essai / tests microbiologiques toxkit

\footnotetext{
*Corresponding author: elenfedoseeva@gmail.com
} 


\section{Introduction: demand for test cultures for environmental testing}

Biotesting for environmental samples is integral to environmental regulations in many countries, including Russia. Lab testing, involving application of 'short-term bioassays' gives results that complement bioindication research data and improve credibility of biodiagnostics of the ecological quality of natural and man-made environments. The drive for extensive application of bioassays in Russian environmental practice was propelled by Criteria for Categorizing Hazardous Wastes by Classes of Environmental Hazard (approved by the RF Ministry for Natural Resources (Order No. 511) enforced in 2001 (FR, 2001). Pursuant to this document, experimental toxicity bioassays based on response of hydrobionts, along with calculations of the concentration of certain toxic components determined by chemical methods, have to be performed for the waste hazard characterization.

A sufficiently broad range of freshwater toxicity bioassays have been devised and are to date used in global practice. The applicability of toxicity bioassays as efficient analytical tools should be supported by their standardization and validation (Keddy et al., 1995; Slabbert and Venter, 1999; Wadhia and Thompson, 2007; Kokkali and van Delft, 2014). According to OECD guidelines (2004, 2006, etc.), principal bioassay aspects to be standardized are methods of preparation of stock and test solutions, details or composition of cultivation and dilution water, incubation conditions (temperature, light intensity and periodicity, dissolved oxygen, $\mathrm{pH}$, etc.). Biological, technological and financial challenges primarily associated with the continuous cultivation and maintenance of test cultures with the desired sensitivity preclude extensive implementing of routine toxicity testing in practice. Welldeveloped research infrastructures are the key components both for the advancement of basic research and generation of state-of-the-art technologies and innovations. Russia does not however have a well-functioning system of supplying users with established and defined test cultures supported with reference or authentication data. Ongoing are vigorous discussions around the creation of national biobanks which over the past decades have been increasingly gaining significance for the standardization of biological sample treatment.

\section{Diversity and quality of test cultures for bioassays}

\subsection{Diversity of test cultures}

Test cultures and detailed procedures for their use are described in international standards or guidelines. The most widely applied standards have been produced by the Organization for Economic Cooperation and Development (OECD) and the International Organization for Standardization (ISO). Standard methods have also been produced by the American Standards for Testing and Materials (ASTM). In Canada, biological test methods are developed by the Environmental Science and Technology Centre and approved by the Environment and Climate Change, and marked as EC (environmental Canada). In the UK, standards are issued by the British Standards Institution (BSI). In Germany, the German Institute for Standardization (DIN - Deutsches Institut für Normung) is in charge of developing standards. The French Association for Standardization (AFNOR) is the French national organization for standardization, which is responsible for the development of standards and technical solutions for evaluation of environmental quality. Russia has a member body in ISO. The national member body that can represent Russia in ISO is the federal agency on technical regulating and metrology (GOST R). GOST R is the federal executive body, implementing inter-industry coordination and functional regulating in the fields of standardization, metrology and conformity assessment (https://www.iso.org/). In Russia, biotesting procedures are defined in state standards and methodologies and presented on two registers. The first is the federal register (FR) that is approved by the federal agency on technical regulation and metrology. The second is the register of environmental regulatory documents (ERD) that is approved by other of national standards body - the environmental protection committee. Table 1 lists the test species for freshwater bioassays covered by standards and guidelines including ISO, OECD and ASTM.

Russian standards have progressed to incorporate the utilisation of freshwater toxicity bioassays employing cells/ organisms such as:

- germinal cells of mammals (cattle) (ERD, 2009);

- crustaceans - Daphnia magna and Ceriodaphnia dubia (ERD, 2007, 2014b; FR, 2007b);

- ciliate holotrichs - Paramecium caudatum (ERD, 2007, 2015);

- microalgae - Pseudokirchneriella subcapatata (formerly known as Selenastrum capricornutum and Raphidocelis subcapitata) and Chlorella vulgaris (ERD, 2011, 2014a, 2014c; FR, 2007a);

- lyophilized bacteria culture - a genetically modified strain of Escherichia coli (ERD, 2010).

An important condition for using bioassays in toxicity assessment pertaining to natural environment is accurate identification of the test species. Many standards, especially those dealing with the use of macrophytes, freshwater algae and cyanobacteria, list "strains shown to be suitable for the test" and specify their sources and collections available for their purchase (OECD, 2006, 2011a; EC, 2007). In particular, algae strains usable for bioassays are ATCC 22662 or CCAP 278/4. Additionally, the standards set requirements for the characteristics of recommended species (appearance, size, cell volume, cell dry weight and growth rate). The description of a strain, source and method of collection, and culture conditions used is an integral part of the test report.

The need for biotesting and the value of the results for inference of quality assessment of natural and man-made environments are regulated by corresponding international and regional legal acts. In the UK, bioassays have been used in a number of statutory roles (Wadhia and Thompson, 2007): (a) in direct toxicity assessment (DTA) for effluent control; (b) in control of emissions under the water resources act and approval for the integrated pollution prevention and control (IPPC); (c) in identification of "special wastes" under the special waste regulations (SWR) under Section 2 of the environmental protection act 1990; and (d) in the UK national 
Table 1. Test species for freshwater toxicity tests.

\begin{tabular}{ll}
\hline \multicolumn{1}{c}{ ISO } & \multicolumn{1}{c}{ OECD } \\
\hline $\begin{array}{l}\text { Vertebrates: amphibians, fishes } \\
\text { Danio rerio (formerly known as } \\
\text { Brachydanio rerio) Hamilton- }\end{array}$ & $\begin{array}{l}\text { Oncorhynchus mykiss; Pimephales } \\
\text { promelas; Danio rerio (formerly } \\
\text { kuchanan (Teleostei, }\end{array}$ \\
$\begin{array}{l}\text { kyprinidae) } \\
\text { Oryzias latipes }\end{array}$ \\
$\begin{array}{l}\text { ISO 7346-1(2,3):1996; } \\
\text { ISO 12890:1999; }\end{array}$ & OECD 210; \\
ISO 15088:2007 & OECD 212 (+C. carpio);
\end{tabular}

\section{Invertebrates: rotifers, worms, mollusks, crustaceans, insects}

Cladoceran crustaceans

Daphnia magna Straus

Daphnia magna Straus

ASTM

Ceriodaphnia dubia

ISO 6341:2012

OECD 202; 211

Ceriodaphnia dubia

ISO 20665:2008

Rotifer Brachionus calyciflorus

ISO 20666:2008

Anostracan crustacean

Thamnocephalus platyurus

Sediment-dwelling larvae of dipteran Chironomus sp.: $C$. riparius; C. tentans; C. yoshimatsui

ISO 14380:2011

OECD 219

Ostracod crustacean

Heterocypris incongruens

ISO 14371:2012

Nematode Caenorhabditis

elegans

\section{ISO 10872:2010}

\section{Plants: algae, higher plants}

Pseudokirchneriella subcapitata (formerly known as Selenastrum capricornutum and Raphidocelis subcapitata); Scenedesmus subspicatus Chodat.

ISO 8692:2012

Lemna minor
Pseudokirchneriella subcapitata (formerly known as Selenastrum capricornutum and Raphidocelis subcapitata); Desmodesmus subspicatus; Navicula pelliculosa; anabaena flos-aquae Synechococcus leopoliensis

OECD 201

D3978-04(2012)

Plants of the genus Lemna (duckweed): L. gibba; L. minor; L. aequinoctialis; L. major; $L$. paucicostata; L. perpusilla; $L$. trisulca; L. valdiviana subcapitata)

Lemna gibba G3
E1295-01 (2013)
E1193-97 (2012)
Ceriodaphnia dubia

Morone saxatilis; Salmon, Trout, and Char; Northern pike; Fathead minnow; White sucker; Channel catfish; Bluegill; Gulf toadfish; Sheepshead minnow; Silversides E1241-05(2013); E176895(2013); E 1711-95 (2008)

Fishes, macroinvertebrates and amphibians

E 729-96 (2007)

Daphnia magna Straus

E1768-95(2013)

Rotifer Brachionus calyciflorus

E1440-91(2012)

Two test organisms, amphipod crustacean Hyalella azteca and midge Chironomus dilutes (formerly known as C. tentans; Shobanov et al., 1999) E1706-05(2010)

Benthic invertebrates (e.g. Diporeia spp. and Lumbriculus variegates)

E1688-10

Bivalve freshwater mollusks belonging to the family Unionidae or Margaritiferidae E2455-06(2013)

Pseudokirchneriella subcapitata (formerly known as Selenastrum capricornutum and Raphidocelis 
Table 1. (continued).

\begin{tabular}{|c|c|c|}
\hline ISO & OECD & ASTM \\
\hline ISO 20079:2005 & OECD 221 & E1415-91(2012) \\
\hline Myriophyllum aquaticum & & $\begin{array}{l}\text { Certain species of freshwater and } \\
\text { saltwater microalgae }\end{array}$ \\
\hline ISO 16191:2013 & & E1218-04(2012) \\
\hline Spirodela polyrhiza & & Macrophytes \\
\hline ISO 20227: 2017 & & E1841-04(2012) \\
\hline \multicolumn{3}{|l|}{ Bacteria } \\
\hline Pseudomonas putida & & $\begin{array}{l}\text { A multi-trophic level freshwater } \\
\text { community }\end{array}$ \\
\hline ISO 10712:1995 & & E1366-11 \\
\hline \multicolumn{3}{|l|}{ Aliivibrio fischeri } \\
\hline \multicolumn{3}{|l|}{ ISO 11348-1:2007 } \\
\hline \multicolumn{3}{|l|}{ Salmonella typhimurium (TA } \\
\hline \multicolumn{3}{|l|}{100 and TA 98; TA1535/ } \\
\hline \multicolumn{3}{|l|}{ pSK1002) } \\
\hline \multicolumn{3}{|l|}{ ISO 11350:2012 } \\
\hline \multicolumn{3}{|l|}{ ISO 11350:2012 } \\
\hline ISO 16240:2005 & & \\
\hline
\end{tabular}

marine monitoring programme (NMMP). In Canada, in compliance with the Canadian environmental protection act, 1999, all substances on Canada's domestic substances list (DSL) must be categorized. Categorization involves evaluation of the substances on the basis of their persistence, bioaccumulation, and inherent toxicity. Categorization of inherent toxicity is based on a criterion of $1 \mathrm{mg} / \mathrm{L}$ for acute LC50 (EC50) values. This numerical cut-off is in agreement with some well-recognized international initiatives such as the organization for economic cooperation (EC, 2003). In Russia, bioassay results are used for waste hazard assessment that is statutory by the RF Ministry for Natural Resources Order No. 536 dated December 4, 2014 (FR, 2014). On approval of the criteria for categorizing wastes by classes of hazard I-V on the basis of the adverse environmental impact level. To characterize hazardous waste an experimental toxicity bioassay based on response of hydrobionts is performed, along with calculations of certain toxic component concentrations determined by chemical methods.

Given such diversity of bioassays test cultures it is necessary to select one that is fit-for-purpose depending on the objectives of the toxicity testing and nature of the test material. The most pertinent and prudent choice of tests should be determined by the relevance of the factors associated with the investigative operation (Wadhia and Thompson, 2007). Each ISO standard precisely defines the application scenarios it applies to and those it does not apply to, or is applicable under certain conditions. For example, "ISO 14380:2011 is not applicable to the testing of unstable chemicals (hydrolyzing, absorbing, etc.) in water unless exposure concentration is measured...", ASTM E 1850-04 describes a standard guide for selection of resident species as test organisms for aquatic and sediment toxicity tests. This standard is as the title suggests designed for guidance in selection of resident species to be used as test organisms in aquatic and sediment toxicity tests and is not exclusively for testing particular chemical types. Guidance on tiered risk assessment for plant protection products for aquatic organisms in edge-of-field surface waters (EFSA, 2013) provides a list of mandatory toxicity tests for effect assessment of various pesticides having different modes of action. For acute effect assessment of pesticides with an insecticidal mode of action, with a herbicidal mode of action and for other pesticides, it is necessary to carry out toxicity tests with Daphnia sp. (D. magna preferred) and Oncorhynchus mykiss. In the case of pesticides with an insecticidal mode of action, additional toxicity tests with another arthropod (e.g. Chironomus sp. or Americamysis bahia) are advisable. For chronic effect assessment of different pesticides, a broader set of toxicity tests has to be performed: Daphnia sp., Chironomus sp. or Lumbriculus sp., green alga (e.g. P. subcapitata) and additional non-green alga (e.g. diatom Navicula pelliculosa), Lemna sp. or Myriophyllum sp. or Glyceria maxima (for pesticides with a herbicidal mode of action).

Evidence of the successful use of a battery of bioassays with different species pertaining to different trophic levels to understand the toxicological profile and to evaluate toxicity of environmental samples and toxicants has been provided in many studies (Doherty et al., 1999; Castillo et al., 2000; Wadhia and Thompson, 2007; Khangarot and Das, 2009). "No single test method or test organism can be expected to satisfy a comprehensive approach to environmental conservation and protection." (EC, 2007). Back in 1998, a battery of six standard ecotoxicity tests was proposed by the French ministry of environment in order to assess hazardous wastes (Slabbert and Venter, 1999). In Russia, it is recommended to use a combination of two bioassays based on responses of species belonging to different taxonomic groups and trophic levels. 


\subsection{Quality of test cultures}

Standardization of toxicity tests, apart from other conditions, demands the evaluation of the sensitivity of test species to reference toxicants (García et al., 2010). Toxicity tests using reference toxicants improve the understanding of certain toxicants' impact on aquatic organisms (Jorge and Moreira, 2005), which can be of help in the selection of the most suitable test organisms (test systems) for analyzing toxicity of particular substances. The use of the most sensitive test organisms (test systems) shows promise for elucidating better water quality information that is more protective of native species (Struewing et al., 2015). In the standards (or guidelines) toxicity tests with reference toxicants are compulsory to assure that the test conditions are reliable, to assess the sensitivity of the organisms at the time the test material or substance is evaluated, and the precision of results obtained by the laboratory for that chemical (OECD, 2004a, 2012a; EC, 2007).

The US EPA document (1994) proposes to use the following compounds as reference toxicants: sodium chloride $\mathrm{NaCl}$, potassium chloride $(\mathrm{KCl})$, cadmium chloride $\left(\mathrm{CdCl}_{3}\right)$, copper sulfate $\left(\mathrm{CuSO}_{4}\right)$, sodium dodecyl sulfate (SDS), and potassium dichromate $\left(\mathrm{K}_{2} \mathrm{Cr}_{2} \mathrm{O}_{7}\right)$. This list is however incomplete and, alongside with these, toxicologists also employ endosulfan, lindane, malathion, pentachlorophenol, ammonium chloride, chloroform, sodium lauryl sulfate, phenol, xylene, carbon tetrachloride, sodium fluoride, and ethyl alcohol (Snell et al., 1991; Khangarot and Das, 2009). A wide range of reference toxicants contributes to a deeper insight into the test organism sensitivity to substances of various nature and action mechanisms. Meanwhile, it is desirable that a reference toxicant meets certain requirements: is easy to measure analytically, poses a minimal hazard to the use and the toxicity of these chemicals is not affected significantly by changes in water quality (EC, 2007). Among the most widely applicable are phenol, $\mathrm{ZnSO}_{4}$ or $\mathrm{CuSO}_{4}$, and $\mathrm{K}_{2} \mathrm{Cr}_{2} \mathrm{O}_{7}$ (Tab. 2). Phenol as a component of dyes, polymers, drugs and other organic substances and a ubiquitous environmental pollutant is a widely used reference toxicant for many bioassays (Ricco et al., 2004; EC, 2007; Michałowicz and Duda, 2007; Park et al., 2012). Some tests require the use of an individual model toxicant. For the freshwater harpacticoid copepod Attheyella crassa, the authors (Turesson et al., 2007) used the fungicide tebuconazole, which is classified as a reproduction toxic substance, as a reference substance.

The toxicity test procedure with reference toxicants suggests testing of the toxicant's sensitivity to serial dilution and evaluation of EC50 or LC50. Russian methodologies (FR, 2007a, 2007b; ERD, 2011, 2014a etc.) indicate a tolerance range for the LC50 (EC50) of a reference toxicant. If the experimentally determined LC50 (EC50) of the test culture falls within this range, it is supposed to be of desired quality and applicable for the bioassay. Other standards set forth a somewhat different procedure that includes a comparison of results for a reference toxicant with historical test results to identify whether they fall within an acceptable range of variability and plotting of a warning chart (EC, 1990, 2005, 2007). Successive ICps (IC50) are plotted on a warning chart and examined to determine whether the results are within \pm 2 standard deviations (= warning limits) or \pm 3 standard deviations (= control limits) of values obtained in previous tests using the same reference toxicant and test procedure. The results that do not fall within the acceptable range indicate a change in the test organism health or genetic sensitivity, a procedural inconsistency, or a combination of these factors.

\section{Standardization of test conditions}

It is impossible to obtain unified and high quality results of ecotoxicological studies without stringent standardization of test conditions. This review will further elaborate on cultivation and dilution water as well as incubation conditions.

\subsection{Water for cultivation and dilution}

The utmost importance of the quality of water used for test culture cultivation and sample dilution has been highlighted in many specialty documents and publications (US EPA, 1994; OECD, 2004a, 2011a, etc.) A few water types can be used for test culture cultivation and dilution: natural water (surface or groundwater), dechlorinated tap water or synthetic water (reconstituted water, artificial media, reagent water) (US EPA, 1994; ISO, 1996; OECD, 2004b, 2011a). The same water is advised for cultivation and dilution. The EC document (2007) recommends control/dilution water for various types of aqueous samples. For effluents, elutriates, leachates: reagent water or receiving water; for receiving water: reagent water or upstream water; for reference toxicants: reagent water; for chemicals: reagent water or receiving water.

The water quality can be assessed against the key indicators such as the salinity, hardness, $\mathrm{pH}$, and dissolved oxygen concentration. Their recommended values vary a little in the corresponding documents of different countries, though generally they fall within the following ranges: alkalinity $-60-70 \mathrm{mg} / \mathrm{L} ; \mathrm{pH}-7.0-8.2$; oxygen $\geq 3-6 \mathrm{mg} / \mathrm{L}$ ( $>60 \%$ of the air saturation value) (EPA guidance for Ceriodaphnia tests, OECD, 2004a, 2011b, 2012a, 2012b; FR, 2007b). The recommended hardness values as $\mathrm{CaCO}_{3}$ indicated in the documents show a greater differentiation: $<400 \mathrm{mg} / \mathrm{L}$ (OECD, 2011b), 140-250 mg/L (OECD, 2004b, 2012b), $250 \pm 25 \mathrm{mg} / \mathrm{L}$ (ISO, 6341), 80-100 mg/L (EPA guidance for Ceriodaphnia tests), and $80-250 \mathrm{mg} / \mathrm{L}$. In addition, a need for monitoring of some other parameters is pinpointed, e.g. amounts of metals, organic carbon, and chlorine and chlorinated derivatives. In accordance with specific standards (APHA, 1992; US EPA, 1994; OECD, 2012b, 2013a) the Al, As, Cr, Co, Fe, Pb, Ni, and Zn content expressed as total metal should not exceed $1 \mu \mathrm{g} / \mathrm{L}$ each; the $\mathrm{Cd}, \mathrm{Hg}$, and $\mathrm{Ag}$ content expressed as total metal should not exceed $100 \mathrm{ng} / \mathrm{L}$ each. Furthermore, total organochlorine pesticides plus PCBs should be less than $50 \mathrm{ng} / \mathrm{L}$. If dilution water is from a natural source, conductivity and total organic carbon (TOC should be $<2 \mathrm{mg} / \mathrm{L}$ ) or chemical oxygen demand (COD should be $<25 \mathrm{ng} / \mathrm{L}$ ) ought to be measured (OECD, 2004b, 2011b). If dechlorinated tap water is used, chlorine analysis is desirable (residual chlorine should be $<10 \mathrm{~m} \mu / \mathrm{L})(\mathrm{OECD}, 2004 \mathrm{~b}, 2011 \mathrm{~b})$. For zebrafish cultivation, Jin et al. (2009) used charcoal filtered water (under semistatic conditions). Special requirements are set for the natural 
V.A. Terekhova et al.: Knowl. Manag. Aquat. Ecosyst. 2018, 419, 32

Table 2. Test species sensitivity to the most widely used reference toxicants.

\begin{tabular}{|c|c|}
\hline Test cultures & $\mathrm{K}_{2} \mathrm{Cr}_{2} \mathrm{O}_{7}$ \\
\hline Cladoceran crustacean & $\begin{array}{l}48 \mathrm{~h} \text { LC50 }=0.2-0.8 \mathrm{mg} / \mathrm{L} \\
\text { (response range) }\end{array}$ \\
\hline Daphnia magna Straus & ERD* ${ }^{*}, 2014 b$ \\
\hline $\begin{array}{l}\text { Cladoceran crustacean } \\
\text { Ceriodaphnia }\end{array}$ & $\begin{array}{l}\text { Ceriodaphnia affinis } \\
24 \mathrm{~h} \text { LC } 50=0.9-2.0 \mathrm{mg} / \mathrm{L} \\
\text { (response range) } \\
\text { ERD, } 2007\end{array}$ \\
\hline $\begin{array}{l}\text { Anostracan crustacean } \\
\text { Thamnocephalus } \\
\text { platyurus }\end{array}$ & $\begin{array}{l}24 \mathrm{~h} \text { LC } 50=0.100 \mathrm{mg} / \mathrm{L} \text { with } \\
95 \% \text { confidence } \operatorname{limit} \text { of } \\
0.052-0.148 \mathrm{mg} / \mathrm{L} \\
\text { International Interlaboratory } \\
\text { Comparison, Protocol Toxkit }\end{array}$ \\
\hline
\end{tabular}

Benthic ostracod

crustacean Heterocypris

incongruens

Amphipod crustacean

Hyalella azteca

Rotifer Brachionus

calyciflorus

Green micro-algae

\section{Selenastrum}

capricornutum

Green micro-algae

Chlorella vulgaris Beijer

Ciliate protozoan

Paramecium caudatum Ehrenberg
Reference toxicants and LC

$\begin{array}{ll}\mathrm{CuSO}_{4} & \text { Phenol } \\ 48 \mathrm{~h} \mathrm{LC} 50=54.6 \mu \mathrm{g} / \mathrm{L} & 48 \mathrm{~h} \mathrm{EC} 50=9.13 \mathrm{mg} / \mathrm{L} \\ 4 \mathrm{~d} \mathrm{LC} 50=34.2 \mu \mathrm{g} / \mathrm{L} & \\ \text { Struewing et al., } 2015 & \text { Lilius et al., } 1995\end{array}$

\section{Ceriodaphnia dubia}

$48 \mathrm{~h} \mathrm{LC50}=27.6 \mu \mathrm{g} / \mathrm{L}$

$7 \mathrm{~d} \mathrm{LC} 50=52.0 \mu \mathrm{g} / \mathrm{L}$

Struewing et al., 2015

6d LC50 $=5.79 \mathrm{mg} / \mathrm{L}$

The results of a reference test with this compound should be in the range $2.21-9.37 \mathrm{mg} / \mathrm{L}$

International Interlaboratory

Comparison, Protocol Toxkit

$7 \mathrm{~d}$ LC50 $=137 \mu \mathrm{gCr} / \mathrm{L}$ with 95\% CL 106-176

$7 \mathrm{~d}$ LC50 $=90 \mu \mathrm{gCu} / \mathrm{L}$ with $95 \%$

CL 82-99

$(\mathrm{Cu}$ was added in tap water as atomic absorption standards)

Borgmann et al., 2005

$24 \mathrm{~h} \mathrm{LC} 50=0.026 \mathrm{mg} / \mathrm{L}$ with $95 \%$ CL $0.022-0.030$

Snell et al., 1991

$24 \mathrm{~h} \mathrm{LC} 50>150 \mathrm{mg} / \mathrm{L}$

Snell et al., 1991
$72 \mathrm{~h} \mathrm{EbC50} \mathrm{(reduction} \mathrm{of}$ biomass $)=0.52 \pm 0.21 \mathrm{mg} / \mathrm{L}$ $72 \mathrm{~h} \mathrm{ErC50}$ (reduction of growth rate $)=0.84 \pm 0.27$ $\mathrm{mg} / \mathrm{L}$

International Interlaboratory Comparison (2006), Protocol Toxkit

$22 \mathrm{~h} \mathrm{EC50} \mathrm{(optical}$ density) $=0.4-1.6 \mathrm{mg} / \mathrm{L}$ (response range) ERD, 2014a $22 \mathrm{~h}$ EC50 (delayed fluorescence $)=0.2-0.8 \mathrm{mg} / \mathrm{L}$ (response range) ERD, 2014c

$24 \mathrm{~d}$ LC50 $=0.55-0.89 \mathrm{~g} / \mathrm{L}$

ERD, 2007
30 min EC50 (chemotoxic reaction $)=0.01-1.0 \mathrm{mg} / \mathrm{L}$ ERD, 2015 
Table 2. (continued).

\begin{tabular}{|c|c|c|c|}
\hline \multirow[t]{2}{*}{ Test cultures } & \multicolumn{3}{|c|}{ Reference toxicants and LC } \\
\hline & $\mathrm{K}_{2} \mathrm{Cr}_{2} \mathrm{O}_{7}$ & $\mathrm{CuSO}_{4}$ & Phenol \\
\hline $\begin{array}{l}\text { Macrophyte Lemna } \\
\text { paucicostata }\end{array}$ & & & $\begin{array}{l}72 \mathrm{~h} \text { EC50 (growth of } \\
\text { fronds) }=2.70 \mu \mathrm{M} \\
72 \mathrm{~h} \text { EC } 50 \text { (maximum quantum } \\
\text { yield of PS II }\left(F_{v} /\right. \\
\left.F_{m}\right)=1.91 \mu \mathrm{M} \\
\text { Park et al., } 2012\end{array}$ \\
\hline $\begin{array}{l}\text { Bacteria } \\
\text { Aliivibrio fischeri }\end{array}$ & & & $\begin{array}{l}\text { Bioluminescence inhibition } \\
5 \mathrm{~min} \text { EC } 50=16.8 \mathrm{mg} / \mathrm{L} \\
15 \mathrm{~min} \text { EC } 50=18.3 \mathrm{mg} / \mathrm{L} \\
\text { Hernando et al., } 2006\end{array}$ \\
\hline
\end{tabular}

${ }^{*}$ Environmental regulatory document.

Table 3. Synthetic water formulations.

\begin{tabular}{|c|c|c|c|}
\hline Macro nutrients & $\begin{array}{c}\text { Standard freshwater } \\
\text { prepared with deionized } \\
\text { water (according to US } \\
\text { EPA, 1994) moderately } \\
\text { hard water }\end{array}$ & $\begin{array}{c}\text { Standard freshwater } \\
\text { prepared with deionized } \\
\text { or distilled water (ISO } \\
\text { medium according to ISO } \\
6341 \text { ) }\end{array}$ & $\begin{array}{c}\text { Medium M4 and M7 } \\
\text { (according to OECD, } \\
2004,2011 \mathrm{~b} \text { ) }\end{array}$ \\
\hline & \multicolumn{3}{|c|}{ Concentration, $\mathrm{mg} / \mathrm{L}$} \\
\hline $\mathrm{NaHCO}_{3}$ & 96 & 67.75 & 64.8 \\
\hline $\mathrm{CaCl}_{2} \cdot 2 \mathrm{H}_{2} \mathrm{O}$ & 120 & 294 & 293.8 \\
\hline $\mathrm{MgSO}_{4} \cdot 7 \mathrm{H}_{2} \mathrm{O}$ & 123 & 123.25 & 123.3 \\
\hline $\mathrm{KCl}$ & 4 & 5.75 & 5.8 \\
\hline $\mathrm{NaSiO}_{3} \cdot 9 \mathrm{H}_{2} \mathrm{O}$ & - & - & 10.0 \\
\hline $\mathrm{NaNO}_{3}$ & - & - & 0.274 \\
\hline $\mathrm{KH}_{2} \mathrm{PO}_{4}$ & - & - & 0.143 \\
\hline $\mathrm{K}_{2} \mathrm{HPO}_{4}$ & - & - & 0.184 \\
\hline
\end{tabular}

water quality because the composition of natural freshwater may change with season and region (Klüttgen et al., 1994). Therefore it is necessary to make sure that water matches the preset characteristics and has constant quality throughout the test. In the case of natural water, the water quality characteristics should be measured at least twice a year or when it is suspected that these characteristics may have changed significantly. The test culture should not express signs of stress and should reproduce well in the water used for cultivation. A dilution water type may depend on the objective of research (US EPA, 1994).

Any constant quality water in which the test species shows suitable long-term survival and growth (OECD, 2012b, 2013a) or reconstituted water in line with ISO 7346 for adult fishes or ISO 12890 for embryo-larval forms can be used for fish cultivation and sample dilution. The synthetic media presently applied that are most successful for culturing successive generations of various invertebrate organisms are listed in Table 3.

The composition of M4 and M7 media (formula according to OECD, 2004a) is rather complex. Apart from macro nutrient elements, these media comprise trace elements and vitamins. The Elendt M4 medium is harder and the amount of trace elements (except for $\mathrm{ZnCl}_{2}, \mathrm{CaCl}_{2} \cdot 6 \mathrm{H}_{2} \mathrm{O}, \mathrm{KI}, \mathrm{Na}_{2} \mathrm{SeO}_{3}$, and $\mathrm{NH}_{4} \mathrm{VO}_{3}$ ) is 4-fold higher than in $\mathrm{M} 7$. The M4 medium was first time described by Elendt and Bias (1990).

It should be noted that, if an interaction is suspected between hardness ions and the test substance, lower hardness water should be used and, thus, Elendt Medium M4 must not be used in this situation (OECD, 2004b, 2011b). The US EPA document (1994) also caters for the preparation of synthetic water with different hardness: very soft, soft, moderately hard, hard, and very hard; however, the most used is moderately hard water. Where natural or dechlorinated water is applied and in order to ensure that the dilution water will not unduly influence the test result (for example by complexation of the test chemical), or adversely affect the performance of the brood stock, samples should be taken at intervals for analysis (OECD, 2004a).

To ensure the required concentration of dissolved oxygen, all synthetic media (the standard freshwater and seawater) used in Toxkit microbiotests must be aerated for at least 15 min prior to use for the hatching of the cysts and for the preparation of the toxicant dilutions. The dissolved oxygen and $\mathrm{pH}$ are measured, as a minimum, in the controls and in the highest test substance 
concentration at the beginning and end of the test. The dissolved oxygen concentration in the controls should be in compliance with the validity criterion. The oxygen level in control and test vessels should be reported as the air saturation value. The $\mathrm{pH}$ should not normally vary by more than 1.5 units over the course of the test (Weltje et al., 2009).

Growth media prepared with deionized water according to the protocols of OECD 201, US EPA medium AAP, and ASTM, are used for freshwater phytoplankton tests. Growth medium, 20X AAP, and modified Swedish standard medium (SIS) for freshwater macrophytes are given in the OECD Guideline 221 "Lemna sp. Growth Inhibition Test" (Tab. 4). Steinberg medium is typically used for aquatic macrophyte culturing and testing (Park et al., 2012).

In the test with the diatom $N$. pelliculosa the media (original medium from OECD TG 201 according to ISO 8692 and US EPA medium AAP according to ASTM) must be supplemented with $\mathrm{Na}_{2} \mathrm{SiO}_{3} \cdot 9 \mathrm{H}_{2} 0$ to obtain a concentration of $1.4 \mathrm{mg} \mathrm{Si} / \mathrm{L}$ (OECD, 2006). The paper by Rahman et al. (2014) clarifies that phytoplankton was cultured in OECD media (OECD , 2011a) at a reduced concentration of total phosphorus $(0.10 \mathrm{mg} / \mathrm{L})$ to more closely reflect natural waters (Dodds et al., 1998). Moreover phosphate concentrations are known to influence As toxicity in phytoplankton (Duester et al., 2011; Levy et al., 2005).

In Russia, the new system for preparing of laboratory water was proposed by researchers of the Faculty of biology of Lomonosov Moscow State University (Filenko et al., 2015). The system consists of three-step purification and "biologization" of tap water. Tap water purified through a flowing filter is put in the first aquarium and dechlorinated two weeks by aeration with atmospheric air with a pump. The water is then transferred to the second aquarium containing quartz sand and higher aquatic plants, which are necessary for its "biologization". Numerous data attest to an active environmental role of the higher aquatic plants and water saturation of metabolites of macrophytes (Kirpenko and Usenko, 2012). Water in the second aquarium is continuously filtered by an external filter (e.g. Tetra EX 600 Plus), which is necessary for water purification from turbidity, mixing of the upper and lower layers of water, and gas exchange. The aquarium is illuminated $12 \mathrm{~h}$ a day. The water in the second aquarium is "biologized" within 14 days. The water is then transferred to the third aquarium with a pump. This water is then ready to be used for the cultivation of aquatic organisms and dilution of the samples in the ecotoxicological tests. The "biologized" water has the following hydrochemical parameters: $\mathrm{pH} 8.0-8.5$; salinity $0.2-0.3 \mathrm{~g} / \mathrm{L}$, the oxygen content $8-11.5 \mathrm{mg} / \mathrm{L}$.

Uspensky, Tamiya and Prat's culture media (ERD, 2011, 2014a) are applied for cultivation and dilution in tests with microalgae (Scenedesmus quadricauda and C. vulgaris). The media formulations are generally similar, varying in salt saturation and Calcium content. The Ca-containing Uspensky's medium, has a different composition from the other growth media.

\subsection{Illumination and temperature}

In addition to the cultivation and dilution water quality, optimal light and temperature conditions (for water and air temperature) have to be maintained. These parameters are of a great physiological value and differ for different groups of aquatic organisms (Snell et al., 1991).

Crustaceans are less demanding in terms of light conditions. Daphnias have eyes capable of rolling to maintain the proper angle with respect to the light source. Light with 3000 lux intensity however inhibits to a certain extent respiration of cladocerans. Vessels with cladocerans should be optimally illuminated by fluorescent lamps in the 500 1000 lux intensity range during 16 hour light and 8 hour dark periods (OECD, 2004a, 2012a; FR, 2007b; ERD, 2014b). Similar requirements for the illumination regime are set for culturing of rotifers Brachionus calyciflorus (ISO, 2008b; ASTM, 2012a), anostraca (fairy shrimps) Thamnocephalus platyurus (ISO, 2011), ostracods Heterocypris incongruens (ISO, 2012a), and larvae of chironomids Chironomus sp. (OECD, 2011b).

Algae culturing requires steady fluorescent lighting, e.g. of the cool-white or daylight type. Strains of algae and cyanobacteria differ in their light demand, therefore light intensity should be tailored for each test culture. For green algae described in the OECD standard (2006) light intensity is recommended to be in the range of 4440-8880 lux, which is equivalent to $60-120 \mu \mathrm{E} \mathrm{m}^{-2} \mathrm{~s}^{-1}$. By Russian standards, the range is somewhat lower, and for freshwater algae $(S$. quadricauda and C. vulgaris) illumination should be within the 3000-5000 lux range (FR, 2007a; ERD, 2011). Some species of cyanobacteria, in particular Anabaena flosaquae, grow well at lower light intensities and may be damaged at high intensities. For such species average light intensity in the range of 2960-4440 lux (equivalent to 40 $60 \mu \mathrm{E} \mathrm{m}^{-2} \mathrm{~s}^{-1}$ ) should be selected (OECD, 2011a). Continuous warm or cool white fluorescent lighting should be used to provide light intensity in the range of 6500 10000 lux $\left(85-135 \mu \mathrm{E} \mathrm{m}^{-2} \mathrm{~s}^{-1}\right)$ for cultivation of Lemna $\mathrm{sp}$. (OECD, 2006).

It is important to understand that light, especially in UVrange, may also affect the toxicity of a contaminant. On one hand, light can also interact with certain contaminant compounds in a phenomenon known as photo-induced, photo-activated, or photo-toxicity (Roberts et al., 2017). The researchers remark that toxicity of metals, polycyclic aromatic hydrocarbons and chlorinated hydrocarbons is enhanced by light ( Wernersson et al., 1999; Roberts et al., 2017). On other hand, light can add to a toxicity decrease in photo-degradable, substances and mixtures. This phenomenon broadly refers to an interaction between a chemical and light resulting in photoinactivation. Such effect is fixed for a wide range of organic, inorganic, and microbial contaminants (Sousa et al., 2013; Na et al., 2018; Rubasinghege et al., 2017).

Thus in all consideration a need for strict monitoring of the lighting conditions is paramount. The ASTM Standard Guide E1733-95(2014) contains information on types of artificial light sources that mimic spectral ranges of the sunlight, light components, calculations of the biologically effective radiation, and other relevant data. The lighting conditions described in the standard are applicable to tests with most organisms and use of most chemicals. Secondly, studying toxicity of difficult substances and mixtures such as photo-degradable substances calls for special biotesting conditions. In short-term acute fish and Daphnia tests breakdown of chemical structures by 
Table 4. Culture medium formulations for macrophytes and phytoplankton.

\begin{tabular}{|c|c|c|c|c|c|c|}
\hline \multicolumn{3}{|c|}{ For macrophytes } & \multicolumn{4}{|c|}{ For phytoplankton (algae and cyanobacteria) } \\
\hline \multirow[t]{2}{*}{ Salts } & $\begin{array}{l}\text { Swedish Standard } \\
\text { (SIS) Lemna } \\
\text { growth medium } \\
\text { according to } \\
\text { OECD } 221\end{array}$ & $\begin{array}{l}20 X \text { AAP growth } \\
\text { medium according } \\
\text { to OECD } 221\end{array}$ & Salts & $\begin{array}{l}\text { Original medium } \\
\text { from OECD TG } \\
201 \text { according to } \\
\text { ISO } 8692\end{array}$ & $\begin{array}{l}\text { US EPA medium } \\
\text { AAP according } \\
\text { to ASTM }\end{array}$ & $\begin{array}{l}\text { Uspensky's } \\
\text { medium according } \\
\text { to ERD, } 2011\end{array}$ \\
\hline & \multicolumn{2}{|c|}{ Concentration, $\mathrm{mg} / \mathrm{L}$} & & \multicolumn{3}{|c|}{ Concentration, $\mathrm{mg} / \mathrm{L}$} \\
\hline $\mathrm{NaNO}_{3}$ & 85 & 510 & $\mathrm{NaHCO}_{3}$ & 50 & 15.0 & - \\
\hline $\mathrm{Na}_{2} \mathrm{CO}_{3}$ & 20 & - & $\mathrm{NaNO}_{3}$ & - & 25.5 & - \\
\hline $\mathrm{NaHCO}_{3}$ & - & 300 & $\mathrm{NH}_{4} \mathrm{Cl}$ & 15 & - & - \\
\hline $\mathrm{KH}_{2} \mathrm{PO}_{4}$ & 13.4 & - & $\mathrm{MgCl}_{2} \cdot 6 \mathrm{H}_{2} \mathrm{O}$ & 12 & 12.16 & - \\
\hline $\mathrm{K}_{2} \mathrm{HPO}_{4} \cdot 3 \mathrm{H}_{2} \mathrm{O}$ & - & 30 & $\mathrm{CaCl}_{2} \cdot 2 \mathrm{H}_{2} \mathrm{O}$ & 18 & 4.41 & - \\
\hline $\mathrm{MgSO}_{4} \cdot 7 \mathrm{H}_{2} \mathrm{O}$ & 75 & 290 & $\mathrm{MgSO}_{4} \cdot 7 \mathrm{H}_{2} \mathrm{O}$ & 15 & 14.6 & 25 \\
\hline $\mathrm{CaCl}_{2} \cdot 2 \mathrm{H}_{2} \mathrm{O}$ & 36 & 90 & $\mathrm{KH}_{2} \mathrm{PO}_{4}$ & 1.6 & - & - \\
\hline $\mathrm{H}_{3} \mathrm{BO}_{3}$ & 1.0 & 3.7 & $\mathrm{~K}_{2} \mathrm{HPO}_{4}$ & - & 1.044 & 25 \\
\hline $\mathrm{MnCl}_{2} \cdot 4 \mathrm{H}_{2} \mathrm{O}$ & 0.2 & 8.3 & $\mathrm{KNO}_{3}$ & - & - & 25 \\
\hline $\mathrm{MnCl}_{2} \cdot 6 \mathrm{H}_{2} \mathrm{O}$ & - & 240 & $\mathrm{~K}_{2} \mathrm{CO}_{3}$ & - & - & 34.5 \\
\hline $\mathrm{Na}_{2} \mathrm{MoO}_{4} \cdot 2 \mathrm{H}_{2} \mathrm{O}$ & 0.01 & $145 \mu \mathrm{g} / \mathrm{L}$ & $\mathrm{FeCl}_{3} \cdot 6 \mathrm{H}_{2} \mathrm{O}$ & 0.064 & 0.160 & - \\
\hline $\mathrm{ZnSO}_{4} \cdot 7 \mathrm{H}_{2} \mathrm{O}$ & 0.05 & - & $\mathrm{H}_{2} \mathrm{BO}_{3}$ & 0.185 & 0.186 & 2.86 \\
\hline $\mathrm{ZnCl}_{2}$ & - & $66 \mu \mathrm{g} / \mathrm{L}$ & $\mathrm{MnCl}_{2}$ & 0.415 & 0.415 & 1.81 \\
\hline $\mathrm{CuSO}_{4} \cdot 5 \mathrm{H}_{2} \mathrm{O}$ & 0.005 & - & $\mathrm{ZnCl}_{2}$ & 0.003 & 0.00327 & \\
\hline $\mathrm{CuCl}_{2} \cdot 2 \mathrm{H}_{2} \mathrm{O}$ & - & $0.24 \mu \mathrm{g} / \mathrm{L}$ & $\mathrm{ZnSO}_{4} \cdot 7 \mathrm{H}_{2} \mathrm{O}$ & - & - & 0.222 \\
\hline $\mathrm{Co}\left(\mathrm{NO}_{3}\right)_{2} \cdot 6 \mathrm{H}_{2} \mathrm{O}$ & 0.01 & - & $\mathrm{CoCl}_{2} \cdot 6 \mathrm{H}_{2} \mathrm{O}$ & 0.0015 & 0.00143 & - \\
\hline $\mathrm{CoCl}_{2} \cdot 6 \mathrm{H}_{2} \mathrm{O}$ & - & $29 \mu \mathrm{g} / \mathrm{L}$ & $\mathrm{CuCl}_{2} \cdot 2 \mathrm{H}_{2} \mathrm{O}$ & 0.00001 & 0.000012 & - \\
\hline $\mathrm{FeCl}_{3} \cdot 6 \mathrm{H}_{2} \mathrm{O}$ & 0.84 & 3.2 & $\mathrm{Na}_{2} \mathrm{MoO}_{4} \cdot 2 \mathrm{H}_{2} \mathrm{O}$ & 0.007 & 0.00726 & - \\
\hline $\mathrm{Na}_{2}$-EDTA $2 \mathrm{H}_{2} \mathrm{O}$ & 1.4 & 6.0 & $\mathrm{Na}_{2}$-EDTA $\cdot 2 \mathrm{H}_{2} \mathrm{O}$ & 0.100 & 0.300 & - \\
\hline MOPS & 490 & - & $\mathrm{MoO}_{3}$ & - & - & 0.01764 \\
\hline- & - & - & $\mathrm{NH}_{4} \mathrm{VO}$ & - & - & 0.02296 \\
\hline
\end{tabular}

photolysis may be reduced or prevented by working in a darkened environment and using red light where necessary (ISO, 1997; OECD, 2000a). In algal tests, it may be possible to determine toxicity of the parent substance using one of two approaches: the first approach is based on selective removal from the illumination source of light wavelengths responsible for photolysis whilst retaining those wavelengths necessary for photosynthesis; the second approach involves carrying out the test using a dark exposure phase followed by an illuminated phase (OECD, 2000b).

A temperature range is specific for each test culture; however, generally, test organisms, for the most part, are mesophilic and need culturing and testing at temperatures in a range of $18-24^{\circ} \mathrm{C}$. Where thermophilic and cryophilic test cultures are used, the temperatures should be higher and lower, respectively. The Russian procedure (ERD, 2014a) provides for the use of a thermophilic strain of $C$. vulgaris, for which the optimal temperature range is $36.0 \pm 0.5^{\circ} \mathrm{C}$. The choice of the temperature sometimes is influenced by the need to minimize the length of the test. In the above mentioned procedure (ERD, 2014a) test lasts $22 \mathrm{~h}$, i.e. it is shorter than other tests with microalgae that last from 48 to $72 \mathrm{~h}$ (ERD, 2011). Temperature can influence the rate of hydrolysis of some substances that degrade in the test system. The adjustment of this parameter, within the range permitted for the test, may therefore be appropriate to optimize exposure concentrations of the parent substance (OECD, 2000a).

\subsubsection{Toxkits}

Biological, technological and financial challenges primarily associated with the continuous cultivation and maintenance of test cultures preclude from implementing toxicity bioassays in practice. Dr Guido Persoone and his research team at the Ghent University and the company MicroBioTests Inc. in Belgium, developed miniature biotests (Toxkit microbiotests) with selected test organisms that are independent from culturing or maintaining of living test cultures (Blaise, 2000; http://www.microbiotests.be/). The major advantage of Toxkit microbiotests, in comparison to conventional bioassays, is that the test organisms are incorporated in the kits in a "dormant" or "immobilized" form, from which they can be activated "on demand", prior to performance of the toxicity test. Data from comparative research of various laboratories in different countries and own interlaboratory exercises on the Toxkits have shown that the sensitivity of the bioassays performed with the microbiotests (Daphtoxkits, Algaltoxkit, Rotoxkit, Thamnotoxkit, Ostracodtoxkit and Spirodela duckweed toxkit) is similar to that of the conventional toxicity tests. Using neonates hatched from cysts for toxicity tests reduces variability in test sensitivity and reduces failure due to excessive control of mortality (Snell et al., 1991). Table 5 gives a brief description of Toxkit microbiotests for freshwater and freshwater sediments with regard to the incubation and testing conditions. Except for 
V.A. Terekhova et al.: Knowl. Manag. Aquat. Ecosyst. 2018, 419, 32

Table 5. Toxkit microbiotests for freshwater and freshwater sediments.

\begin{tabular}{|c|c|c|c|c|}
\hline Test & Test species & $\begin{array}{l}\text { Hatching/Incubation } \\
\text { conditions }\end{array}$ & Testing conditions & $\begin{array}{l}\text { Culturing and dilution } \\
\text { medium }\end{array}$ \\
\hline Toxi-Screening kit & $\begin{array}{l}\text { Freeze-dried luminescent } \\
\text { bacteria Aliivibrio fischeri }\end{array}$ & - & $\begin{array}{l}\text { At ambient temperature } \\
\text { within the range } 15^{\circ} \mathrm{C}- \\
25^{\circ} \mathrm{C}\end{array}$ & Control water \\
\hline Chronic protoxkit $\mathrm{F}$ & $\begin{array}{l}\text { Ciliate Tetrahymena } \\
\text { thermophila }\end{array}$ & - & In darkness at $30^{\circ} \mathrm{C}$ & Protoxit medium \\
\hline Acute rotoxkit $\mathrm{F}$ & $\begin{array}{l}\text { Rotifer Brachionus } \\
\text { calyciflorus }\end{array}$ & $\begin{array}{l}\text { At } 25^{\circ} \mathrm{C} \text {, under continuous } \\
\text { illumination (light source } \\
\text { of min. } 3000-4000 \text { lux), } \\
16-18 \mathrm{~h}\end{array}$ & $\begin{array}{l}\text { At } 25^{\circ} \mathrm{C} \text { in darkness, for } \\
24 \mathrm{~h}\end{array}$ & $\begin{array}{l}\text { Moderately hard synthetic } \\
\text { water, US EPA formula }\end{array}$ \\
\hline Short-chronic rotoxkit F & $\begin{array}{l}\text { Rotifer Brachionus } \\
\text { calyciflorus }\end{array}$ & $\begin{array}{l}\text { At } 25^{\circ} \mathrm{C} \text {, under continuous } \\
\text { illumination (light source } \\
\text { of min. } 3000-4000 \text { lux), } \\
16-18 \mathrm{~h}\end{array}$ & $\begin{array}{l}\text { At } 25^{\circ} \mathrm{C} \text { in darkness, for } \\
24 \mathrm{~h}\end{array}$ & $\begin{array}{l}\text { Moderately hard synthetic } \\
\text { water, US EPA formula }\end{array}$ \\
\hline Daph toxkit $F$ magna & $\begin{array}{l}\text { Cladoceran crustacean } \\
\text { Daphnia magna }\end{array}$ & $\begin{array}{l}\text { At } 20-22^{\circ} \mathrm{C} \text { under } \\
\text { continuous illumination of } \\
\text { min. } 6000 \operatorname{lux}, 72 \mathrm{~h}\end{array}$ & At $20^{\circ} \mathrm{C}$, in darkness & $\begin{array}{l}\text { ISO medium, formula } \\
\text { according to ISO } 6341\end{array}$ \\
\hline Thamno toxkit $\mathrm{F}$ & $\begin{array}{l}\text { Anostracan crustacean } \\
\text { Thamnocephalus } \\
\text { platyurus }\end{array}$ & $\begin{array}{l}\text { At } 25^{\circ} \mathrm{C} \text {, under continuous } \\
\text { illumination (light source } \\
\text { of min. } 3000-4000 \text { lux), } \\
20-22 \mathrm{~h}\end{array}$ & $\begin{array}{l}\text { At } 25^{\circ} \mathrm{C} \text { in darkness, for } \\
24 \mathrm{~h}\end{array}$ & $\begin{array}{l}\text { Moderately hard synthetic } \\
\text { water, US EPA formula }\end{array}$ \\
\hline Ostracod toxkit F & $\begin{array}{l}\text { Benthic ostracod } \\
\text { crustacean Heterocypris } \\
\text { incongruens }\end{array}$ & $\begin{array}{l}\text { At } 25^{\circ} \mathrm{C} \text {, under continuous } \\
\text { illumination (light source } \\
\text { of min. } 3000-4000 \text { lux), } \\
52 \mathrm{~h}\end{array}$ & $\begin{array}{l}\text { At } 25^{\circ} \mathrm{C} \text {, in darkness, for } \\
6 \text { days }\end{array}$ & $\begin{array}{l}\text { Moderately hard synthetic } \\
\text { water, US EPA formula }\end{array}$ \\
\hline Ceriodaphtoxkit & $\begin{array}{l}\text { Cladoceran crustacean } \\
\text { Ceriodaphnia dubia }\end{array}$ & $\begin{array}{l}\text { At } 25^{\circ} \mathrm{C} \text {, under continuous } \\
\text { illumination of min. } \\
6000 \text { lux, about } 80 \mathrm{~h}\end{array}$ & $\begin{array}{l}\text { At } 25^{\circ} \mathrm{C} \text {, in darkness, for } \\
24 \mathrm{~h}\end{array}$ & $\begin{array}{l}\text { Moderately hard synthetic } \\
\text { water, US EPA formula }\end{array}$ \\
\hline Rapid toxkit & $\begin{array}{l}\text { Anostracan crustacean } \\
\text { Thamnocephalus } \\
\text { platyurus }\end{array}$ & $\begin{array}{l}\text { At } 25^{\circ} \mathrm{C} \text {, under continuous } \\
\text { illumination (light source } \\
\text { of min. } 3000-4000 \mathrm{lux} \text { ), } \\
\text { for } 30 \mathrm{~h} \text { (minimum) to } 45 \mathrm{~h} \\
\text { (maximum) }\end{array}$ & $\begin{array}{l}\text { For } 15 \text { to } 30 \mathrm{~min} \text { at } 25^{\circ} \mathrm{C} \\
\text { in darkness }\end{array}$ & $\begin{array}{l}\text { Moderately hard synthetic } \\
\text { water, US EPA formula }\end{array}$ \\
\hline Algal toxkit $\mathrm{F}$ & $\begin{array}{l}\text { Green micro-algae } \\
\text { Pseudokirchneriella } \\
\text { subcapitata (formerly } \\
\text { known as Selenastrum } \\
\text { capricornutum and } \\
\text { Raphidocelis subcapitata) }\end{array}$ & - & $\begin{array}{l}23^{\circ} \mathrm{C}+2{ }^{\circ} \mathrm{C} \text { with constant } \\
\text { uniform illumination from } \\
\text { cool white fluorescent } \\
\text { lamps: } 10000 \text { lux for } \\
\text { sideway illumination of } \\
\text { the holding tray or } 3000- \\
4000 \text { lux for bottom } \\
\text { illumination }\end{array}$ & $\begin{array}{l}\text { Algal culturing medium } \\
\text { with deionized water, } \\
\text { according to the formula } \\
\text { of the OECD guideline } \\
201 \text { and the ISO/DIS } \\
\text { guideline } 8692\end{array}$ \\
\hline $\begin{array}{l}\text { Spirodela duckweed } \\
\text { toxkit }\end{array}$ & $\begin{array}{l}\text { Macrophyte Spirodela } \\
\text { polyrhiza }\end{array}$ & $\begin{array}{l}\text { At } 25^{\circ} \mathrm{C} \text { with continuous } \\
\text { "top" illumination (at least } \\
6000 \text { lux at the surface of } \\
\text { the petri dish) }\end{array}$ & $\begin{array}{l}\text { At } 25^{\circ} \mathrm{C} \text { with continuous } \\
\text { illumination of } 6000 \mathrm{lux} \\
\text { (at the top of the } \\
\text { multiwell), } 3 \text { days } \\
(72 \mathrm{~h}+1 \mathrm{~h})\end{array}$ & $\begin{array}{l}\text { The growth medium is the } \\
\text { "Steinberg medium" } \\
\text { prescribed by ISO for } \\
\text { Lemna toxicity tests (ISO } \\
20079 \text { ) }\end{array}$ \\
\hline
\end{tabular}


algal and duckweed tests which require illumination, the tests are for the most part performed in darkness, which creates stable conditions for difficult substances and mixtures. Synthetic media are used for culturing and dilution thereby facilitating water quality analysis. Standard operational procedures prescribe in detail and step by step the implementation of the microbiotests.

\section{Conclusion}

The review of the literature sources and regulatory documents on the standardized biological test species and their cultures presently applied for establishing the extent of environment toxicity and safety testifies to a great diversity of approaches and living organisms being in practical use. Nevertheless, we have to acknowledge that their use and application globally and in Russia lacks uniformity or co-ordinated monitoring.

Test organism species and strains as well as the quality of collections vary across organizations. The organisms used for biotesting are most comprehensively represented in universities and research centers but they reflect significant variability aligned to individual interests and research focus of the investigators. It is regretful that, once laboratories are restructured or shutdown, the collections are often not maintained and no longer exist.

The insufficient number of ecoanalytical laboratories with standardized cultures of test organisms impedes toxicological research progress and the generation of pertinent information on environmental risk assessment which is essential for the ecosystem health. The use of biological tools from odd sources, without the guaranteed species identification and standard-compliant sensitivity to reference substances does not further the unification of the approaches to environmental assessment of natural media, wastes and other materials.

The relevance and need of creating coordination center(s) for the dissemination of test cultures is obvious. Research infrastructure in the form of a centralized network of users would provide users verified test cultures supported with reference data.

Acknowledgments. This research was funded by the Russian Science Foundation (grant number 14-50-00029).

\section{References}

APHA. 1992. Standard methods for examination of water and waste water. Washington, DC, USA: APHA.

ASTM. 2007. Standard guide for conducting acute toxicity tests on test materials with fishes, macroinvertebrates and amphibians. Philadelphia, PA, USA: ASTM Standard, pp. E729-E796.

ASTM. 2008. Standard guide for measurement of behavior during fish toxicity tests. Philadelphia, PA, USA: ASTM Standard, pp. E1711-E1795.

ASTM. 2010. Standard test method for measuring the toxicity of sediment-associated contaminants with freshwater invertebrates. Philadelphia, PA, USA: ASTM Standard, E1706 p.

ASTM. 2011. Standard practice for standardized aquatic microcosms: fresh water. Philadelphia, PA, USA: ASTM Standard E1366-11.

ASTM. 2012a. Standard guide for acute toxicity test with the rotifer brachionus. Philadelphia, PA, USA: ASTM Standard E1440-91.

ASTM. 2012b. Standard guide for conducting Daphnia magna life-cycle toxicity tests. Philadelphia, PA, USA: ASTM Standard E1193-97.
ASTM. 2012c. Standard guide for selection of resident species as test organisms for aquatic and sediment toxicity tests. Philadelphia, PA, USA: ASTM Standard E 1850-04.

ASTM. 2012d. Standard practice for algal growth potential testing with Pseudokirchneriella subcapitata. Philadelphia, PA, USA: ASTM Standard D3978-04.

ASTM. 2012e. Standard guide for conducting static toxicity tests with microalgae. Philadelphia, PA, USA: ASTM Standard E1218-04.

ASTM. 2012f. Standard guide for conducting static toxicity tests with Lemna gibba G3. Philadelphia, PA, USA: ASTM Standard E1415-91.

ASTM. 2012g. Standard guide for conducting renewal phytotoxicity tests with freshwater emergent macrophytes. Philadelphia, PA, USA: ASTM Standard E1841-04.

ASTM. 2013a. Standard guide for ventilatory behavioral toxicology testing of freshwater fish. Philadelphia, PA, USA: ASTM Standard E1768-95.

ASTM. 2013b. Standard guide for conducting early life-stage toxicity tests with fishes. Philadelphia, PA, USA: ASTM Standard E1241-05.

ASTM. 2013c. Standard guide for conducting three-brood, renewal toxicity tests with Ceriodaphnia dubia. Philadelphia, PA, USA: ASTM Standard E1295-01.

ASTM. 2013d. Standard guide for conducting laboratory toxicity tests with freshwater mussels. Philadelphia, PA, USA: ASTM Standard E2455-06.

ASTM. 2014. Standard guide for use of lighting in laboratory testing. Philadelphia, PA, USA: ASTM Standard E1733-95.

ASTM. 2016. Standard guide for determination of the bioaccumulation of sediment-associated contaminants by benthic invertebrates. Philadelphia, PA, USA: ASTM Standard E1688-10.

Blaise C. 2000. Canadian application of microbiotests to assess the toxic potential of complex liquid and solid media. In Persoone G, Janssen C, Coen WD, eds. New microbiotests for routine toxicity screening and biomonitoring. New York: Kluwer Academic/ Plenum Publishers, pp. 3-12.

Borgmann U, Couillard Y, Doyle P, Dixon G. 2005. Toxicity of sixtythree metals and metalloids to Hyalella azteca at two levels of water hardness. Environ Toxicol Chem 24: 641-652.

Castillo GC, Vila IC, Neild E. 2000. Ecotoxicity assessment of metals and wastewater using multitropic assays. Environ Toxicol 15: $370-375$.

Dodds WK, Jones JR, Welch EB. 1998. Suggested classification of stream trophic state: distributions of temperate stream types by chlorophyll, total nitrogen, and phosphorus. Water Res 32: 1455-1462.

Doherty FG, Qureshi AA, Razza JB. 1999. Comparison of the Ceriodaphnia dubia and Microtox ${ }^{\mathrm{R}}$ inhibition tests for toxicity assessment of industrial and municipal wastewaters. Environ Toxicol 14: 375-382.

Duester L, Van Der Geest HG, Moelleken S, Hirner AV, Kueppers K. 2011. Comparative phytotoxicity of methylated and inorganic arsenic and antimony species to Lemna minor, Wolffia arrhiza and Selenastrum capricornutum. Microchem J 97: 30-37.

EC. 1990. Guidance document on control of toxicity test precision using reference toxicants, conservation and protection, environmental protection. Report EPS 1/RM/12, Ottawa, Canada.

EC. 2003. Guidance manual for the categorization of organic and inorganic substances on Canada's domestic substances list. Existing Substances Branch. Report PQ.2, Gatineau, Canada.

EC. 2005. Guidance document on statistical methods for environmental toxicity tests. Method development and applications section. Report EPS 1/RM/46, Ottawa, Canada.

EC. 2007. Biological test method: growth inhibition test using a freshwater alga. Environmental protection series. Report EPS 1/ RM/25, Ottawa, Canada. 
EFSA. 2013. EFSA guidance on tiered risk assessment for plant protection products for aquatic organisms in edge-of-field surface waters. EFSA J 11: 3290.

Elendt BP, Bias WR. 1990. Trace nutrient deficiency in Daphnia magna cultured in standard medium for toxicity testing. Effects of the optimization of culture conditions on life history parameters of D. magna. War Res 24: 1157-1167.

ERD. 2007. Methodology for evaluating ash and slag waste toxicity by the bioassay method based on the survival rate of Paramecia and Ceriodaphnia (In Russian). ERD F T 16.3.12-07. Moscow, Russia.

ERD. 2009. Methodology for measuring the toxicity index in soils, potting soils, waters and wastes on the basis of in vitro mobility changes of germinal cells in mammals (In Russian). ERD F T 14.1:2:4.15-09; T 16.1:2:2.3:3.13-09. Moscow, Russia.

ERD. 2010. Methodology for evaluating integral toxicity of surface waters, including sea, ground, potable and waste water extracts from soils; soils, wastes, and wastewater sludge by the change in the bacterial bioluminescence using an Ecolum test kit (In Russian). ERD F T 14.1:2:3:4.11-04; T 16.1:2.3:3.8-04. Moscow, Russia.

ERD. 2011. Methodology for evaluating acute toxicity of potable, fresh natural and waste waters, water extracts from soils and wastes by the change in the optical density of the Scenedesmus alga culture (Scenedesmus quadricauda; (Turp.) Breb.) (In Russian). ERD F T 14.1:2:4.17-2011; T16.1:2.3:3.18-2011. Moscow, Russia.

ERD. 2014a. Methodology for measuring the optical density of the chlorella alga culture (Chlorella vulgaris Beijer) for toxicity assessment of potable, fresh natural and waste waters, water extracts from grounds, soils, wastewater sludge, and industrial and domestic wastes (In Russian). ERD F T 14.1:2:3:4.10-04; T 16.1:2:2.3:3.7-04. Moscow, Russia.

ERD. 2014b. Methodology for measuring the number of Daphnia magna Straus for toxicity assessment of potable, fresh natural and waste waters, water extracts from grounds, soils, wastewater sludge, and industrial and domestic wastes by the counting up method (In Russian). ERD F T 14.1:2:3:4.12-06; T 16.1:2:2.3:3.9-06. Moscow, Russia.

ERD. 2014c. Methodology for measuring the relative index of the delayed fluorescence of the chlorella alga culture (Chlorella vulgaris Beijer) for toxicity assessment of potable, fresh natural and waste waters, water extracts from grounds, soils, wastewater sludge, and industrial and domestic wastes (In Russian). ERD F T 14.1:2:4.16-09; T 16.1:2.3:3.14-09. Moscow, Russia.

ERD. 2015. Methodology for evaluating toxicity of soil, bottom sediment and wastewater sludge samples by the short-term bioassay method using a Biotester series instrument (In Russian). ERD F T 16.2:2.2-98. Moscow, Russia.

Filenko OF, Isakova EF, Hershkowitz DM, Ipatova VI, Dmitrieva AG. 2015. Biological testing of the quality of the environment using aquatic organisms, Teaching manual. Moscow: Moscow state University, 44 p. (In Russian).

FR. 2001. On approval of the criteria for categorizing hazardous wastes by classes of environmental hazard (terminated) (In Russian). Moscow, Russia.

FR. 2007a. Methodology for evaluating toxicity of water and water extracts from soils, wastewater sludge and wastes by the change in the chlorophyll fluorescence and in the number of algae cells (In Russian). FR 1.39.2007.03223. Moscow, Russia.

FR. 2007b. Methodology for evaluating toxicity of water and water extracts from soils, wastewater sludge and wastes by mortality and the fertility change in daphnia (In Russian). FR 1.39.2007.03222. Moscow, Russia.
FR. 2014. On approval of the criteria for categorizing wastes by classes of hazard I - V on the basis of the adverse environmental impact level (registered at the RF Ministry of Justice as of December 122015 No. 40330) (In Russian). Moscow, Russia.

García ME, Rodrígues CA, Ferrari L. 2010. Age-related differential sensitivity to cadmium in Hyalella curvispina (Amphipoda) and implications in ecotoxicity studies. Ecotoxicol Environ Saf 73: 771-778.

Ge L, Na G, Chen C-E., Li J, Ju M, Wang Y, Li K, Zhang P, Yao Z. 2016. Aqueous photochemical degradation of hydroxylated PAHs: kinetics, pathways, and multivariate effects of main water constituents. Sci Total Environ 547: 166-172.

Hernando MD, Malato O, Farré M, Fernandez-Alba AR, Barceló D. 2006. Application of ring study: water toxicity determinations by bioluminescence assay with Vibrio fischeri. Talanta 69: 370-376. https://www.iso.org/

ISO. 1995. Water quality - Pseudomonas putida growth inhibition test (Pseudomonas cell multiplication inhibition test). Geneva, Switzerland: ISO Standard 10712.

ISO. 1996. Water quality - Determination of the acute lethal toxicity of substances to a freshwater fish [Brachydanio rerio HamiltonBuchanan (Teleostei, Cyprinidae)]. Geneva, Switzerland: ISO Standard 7346-1 (2, 3).

ISO. 1997. Water quality - Sampling - Part 16: guidance on biotesting of samples. Geneva, Switzerland: ISO Standard 5667/ 16.

ISO. 1999. Water quality - Determination of toxicity to embryos and larvae of freshwater fish - Semi-static method. Geneva, Switzerland: ISO Standard 12890.

ISO. 2000. Water quality - Determination of long term toxicity of substances to Daphnia magna Straus (Cladocera, Crustacea). Geneva, Switzerland: ISO Standard 10706.

ISO. 2005a. Water quality - Determination of the genotoxicity of water and waste water - Salmonella/microsome test (Ames test). Geneva, Switzerland: ISO 16240.

ISO. 2005b. Water quality - Determination of the toxic effect of water constituents and waste water on duckweed (Lemna minor). Duckweed growth inhibition test. Geneva, Switzerland: ISO Standard 20079.

ISO. 2007a. Water quality - Determination of the acute toxicity of waste water to zebrafish eggs (Danio rerio). Geneva, Switzerland: ISO Standard 15088.

ISO. 2007b. Water quality - Determination of the inhibitory effect of water samples on the light emission of Vibrio fischeri (Luminescent bacteria test) - Part 1: method using freshly prepared bacteria. Geneva, Switzerland: ISO Standard 11348-1.

ISO. 2008a. Water quality - Determination of chronic toxicity to Ceriodaphnia dubia. Geneva, Switzerland: ISO Standard 20665.

ISO. 2008b. Water quality - Determination of the chronic toxicity to Brachionus calyciflorus in $48 \mathrm{~h}$. Geneva, Switzerland: ISO Standard 20666.

ISO. 2010. Water quality - Determination of the toxic effect of sediment and soil samples on growth, fertility and reproduction of Caenorhabditis elegans (Nematoda). Geneva, Switzerland: ISO Standard 10872.

ISO. 2011. Water quality - Determination of the acute toxicity to Thamnocephalus platyurus (Crustacea, Anostraca). Geneva, Switzerland: ISO Standard 14380. 
ISO. 2012a. Water quality - Determination of fresh water sediment toxicity to Heterocypris incongruens (Crustacea, Ostracoda). Geneva, Switzerland: ISO Standard 14371.

ISO. 2012b. Water quality - Determination of the inhibition of the mobility of Daphnia magna Straus (Cladocera, Crustacea) - Acute toxicity test. Geneva, Switzerland: ISO Standard 6341.

ISO. 2012c. Water quality - Fresh water algal growth inhibition test with unicellular green algae. Geneva, Switzerland: ISO Standard 8692.

ISO. 2012d. Water quality - Determination of the genotoxicity of water and waste water - Salmonella/microsome fluctuation test (Ames fluctuation test). Geneva, Switzerland: ISO Standard 11350.

ISO. 2013. Water quality - Determination of the toxic effect of sediment on the growth behaviour of Myriophyllum aquaticum. Geneva, Switzerland: ISO Standard 16191.

ISO. 2017. Water quality - Determination of the growth inhibition effects of waste waters, natural waters and chemicals on the duckweed Spirodela polyrhiza - Method using a stock culture independent microbiotest. Geneva, Switzerland: ISO Standard 20227.

Jin H, Sood R, Xu J, Zhen F, English MA, Liu PP, Wen Z. 2009. Definitive hematopoietic stem/progenitor cells manifest distinct differentiation output in the zebrafish VDA and PBI. Development 136: 647-654.

Jorge RA, Moreira GS. 2005. Use of sodium dodecyl sulfate and zinc sulfate as reference substances for toxicity test with the mussel Perna perna (Linnaeus, 1758) (Mollusca: Bivalva). Ecotoxicol Environ Saf 61: 280-285.

Keddy CJ, Greene JC, Bonnell MA. 1995. Review of wholeorganisms bioassays: soil, freshwater sediment and freshwater assessment in Canada. Ecotoxicol Environ Saf 30: 221-251.

Khangarot BS, Das S. 2009. Acute toxicity of metals and reference toxicants to a freshwater ostracod, Cypris subglobosa Sowerby, 1840 and correlation to $\mathrm{EC}_{50}$ values of other test models. J Hazard Mater 172: 641-649.

Kirpenko N, Usenko OM. 2012. The influence of higher aquatic plants on microalgae (a review). Hydrobiol J 48: 66-88 (In Russian).

Klüttgen B, Dülmer U, Engels M, Ratte HT. 1994. Adam, an artificial freshwater for the culture of zooplankton. War Res 28: 743-746.

Kokkali V, van Delft W. 2014. Overview of commercially available bioassays for assessing chemical toxicity in aqueous samples. Trends Anal Chem 61: 133-155.

Levy JL, Stauber JL, Adams MS, Maher WA, Kirby JK, Jolley DF. 2005. Toxicity, biotransformation, and mode of action of arsenic in two freshwater microalgae (Chlorellasp. And Monoraphidium arcuatum). Environ Toxicol Chem 24: 2630-2639.

Lilius H, Hastbacka T, Iosmaa BA. 1995. Comparison of the toxicity of 30 reference chemicals to Daphnia magna and Daphnia pulex. Environ Toxicol Chem 4: 2085-2088.

Michałowicz, J, Duda W. 2007. Phenols—sources and toxicity. Pol J Environ Stud 16: 347-362.

Na G, Lu Z, Gao H, Zhang L, Li Q, Li R, Yang F, Huo C, Ya Z. 2018. The effect of environmental factors and migration dynamics on the prevalence of antibiotic-resistant Escherichia coli in estuary environments. Sci Rep. 8: 1663.

OECD. 1998. Fish, short-term toxicity test on embryo and sac-fry stages. OECD Test No. 212. Paris, France.

OECD. 2000a. Guidance document on aquatic toxicity testing of difficult substances and mixtures. OECD series on testing and assessment, Number 23, ENV/JM/MONO(2000)6. Paris, France.
OECD. 2000b. Fish, juvenile growth. OECD Test No. 215. Paris, France.

OECD. 2004a. Daphnia sp. acute immobilization test. OECD Test No. 202. Paris, France.

OECD. 2004b. Sediment-water chironomid toxicity using spiked water. OECD Test No. 219. Paris, France.

OECD. 2006. Lemna sp. growth inhibition test. OECD Test No. 221. Paris, France.

OECD. 2011a. Freshwater alga and cyanobacteria, growth inhibition test. OECD Test No. 201. Paris, France.

OECD. 2011b. Chironomus sp., acute immobilization test. OECD Test No. 235. Paris, France.

OECD. 2012a. Daphnia magna reproduction test. OECD Test No. 211. Paris, France.

OECD. 2012b. Fish short term reproduction assay. OECD Test No. 229. Paris, France.

OECD. 2013a. Fish embryo acute toxicity (FET) Test. OECD Test No. 236. Paris, France.

OECD. 2013b. Fish, Early-life stage toxicity test. OECD Test No. 210. Paris, France.

Park J-S., Brown MT, Han T. 2012. Phenol toxicity to the aquatic macrophyte Lemna paucicostata. Aquat Toxicol 106: 182-188.

Rahman AM, Ben H, Elliott D, Christopher D, Rick K, Rahman MM, Ravi N, Richard PL, William M, Christel H. 2014. Toxicity of arsenic species to three freshwater organisms and biotransformation of inorganic arsenic by freshwater phytoplankton (Chlorella sp. CE-35). Ecotoxicol Environ Saf 106: 126-135.

Ricco G, Tomei MC, Ramadori R, Laera G. 2004. Toxicity assessment of common xenobiotic compounds on municipal activated sludge: comparison between respirometry and Microtox ${ }^{\circledR}$. Water Res 38: 2103-2110.

Roberts AP, Alloy MM, Oris JT. 2017. Review of the photo-induced toxicity of environmental contaminants. Comp Biochem Physiol Part C Toxicol Pharmacol 191: 160-167.

Rubasinghege G, Gurung R, Rijal H, Maldonado-Torres S, Chan A, Acharya S, Rogelj S, Piyasena M. 2017. Abiotic degradation and environmental toxicity of ibuprofen: roles of mineral particles and solar radiation. Water Res 131: 22-32.

Slabbert JL, Venter EA. 1999. Biological assays for aquatic toxicity testing. Water Sci Technol 29: 367-373.

Snell TW, Moffat BD, Janssen C, Persoone G. 1991. Acute toxicity tests using rotifers: IV. Effects of cyst age, temperature, and salinity on the sensitivity of Brachionus calyciflorus. Ecotoxicol Environ Saf 21: 308-317.

Sousa VM, Manaia CM, Mendes A, Nunes OC. 2013. Photoinactivation of various antibiotic resistant strains of Escherichia coli using a paint coat. J Photochem Photobiol A Chem 251: 148153.

Struewing KA, Lazorchak JM, Weaver PC, Johnson BR, Funk DH, Buchwalter DB. 2015. Part 2: sensitivity comparisons of the mayfly Centroptilum triangulifer to Ceriodaphnia dubia and Daphnia magna using standard reference toxicants; $\mathrm{NaCl}, \mathrm{KCl}$ and $\mathrm{CuSO}_{4}$. Chemosphere 139: 597-603.

Turesson EU, Stiernström S, Minten J, Adolfsson-Erici M, Bengtsson B-E, Brietholtz M. 2007. Development and reproduction of the freshwater harpacticoid copepod Attheyella crassa for assessing sediment-associated toxicity. Aquat Toxicol 83: 180-189.

US EPA. 1994. Methods for measuring the acute toxicity of effluents and receiving waters to freshwater and marine organisms, 4th ed. Washington, DC, USA: EPA. 
Ulfsdotter TE, Stiernstrom S, Minten J, Adolfsson-Erici M, Bengtsson BE, Breitholtz M. 2007. Development and reproduction of the freshwater harpacticoid copepod Attheyella crassa for assessing sediment-associated toxicity. Aquat Toxicol 83: 180-189.

Wadhia K, Thompson KC. 2007. Low-cost ecotoxicity testing of environmental samples using microbiotests for potential implementation of the Water Framework Directive. Trends Anal Chem 26: $307-322$.
Weltje L, Rufli H, Heimbach F, Wheeler J, Vervliet-Scheebaum M, Hamerk M. 2009. The chironomid acute toxicity test: development of a new test system. Integr Environ Assess Manag 6: 301307.

Wernersson AS, Dave G, Nilsson E. 1999. Combining sediment quality criteria and sediment bioassays with photoactivation for assessing sediment quality along the Swedish West Coast. Aquat Ecosyst Health Manag 2: 379-389.

Cite this article as: Terekhova VA, Wadhia K, Fedoseeva EV, Uchanov PV. 2018. Bioassay standardization issues in freshwater ecosystem assessment: test cultures and test conditions. Knowl. Manag. Aquat. Ecosyst., 419, 32. 